example, list Borradaile's "Manual of Zoology" and leave out Grove and Newell's "Animal Biology"? There is no reference to the two latest volumes of Hyman's work on the invertebrates published in 1951. Then again, in the general books on vertebrates, J. Z. Young's "The Life of the Vertebrates" and Romer's "The Vertebrate Body" are omitted. In the general books on Mammalia, Harrison Matthew's excellent account of British mammals in the New Naturalist series is not included.

There are also strange omissions in the lists of key works of the groups. In the Mollusca one would have thought that Thiele would have been given. The reference to Step, "Shell Life", is to the 1926 edition; but there was a revised edition in 1945 .

These are a few examples; but they tend to weaken one's confidence in the comprehensiveness of the lists. The work gives an impression that the consultative net might have been cast a little wider among zoologists in general and the specialists in the various groups. Perhaps a third edition will not be too long delayed, and it is to be hoped that the editors in their laborious task will take comfort in the thought that they are earning the genuine gratitude of zoologists and botanists both at home and abroad.

The greatly extended list of references to monographs of special groups of flowering plants is a very valuable feature of the botanical section of this work, and one for which systematic botanists will be grateful. The exclusion of Schinz and Keller (given in the first edition) from the foreign books is to be regretted, and Raunkiaer's "Dansk EkskursionsFlora" might well have been added. These, however, are minor blemishes in an admirable and comprehensive list of botanical works.

H. P. MOON

T. G. TUTIN

\section{"DOFLEIN'S PROTOZOA"}

\section{Lehrbuch der Protozoenkunde}

Eine Darstellung der Naturgeschichte der Protozoen mit besonderer Berücksichtigung der parasitischen und pathogenen Formen. Sechste Auflage. Zweiter Teil: Spezielle Naturgeschichte der Protozoen. Zweite Hälfte : Sporozoa und Ciliophora. Begründet von Franz Doflein; fortgesetzt von Prof. Dr. Eduard Reichenow. Pp. iv + 777-1214. (Jena: Gustav Fischer Verlag, 1953.) 23.50 D. marks.

THE first and more general part of this invaluable book has already been reviewed (Nature, 167, $829 ; 1951$, and the commendations of that part then recorded apply also to the second part, which has been published as two paper-backed volumes, the first deeling with the Mastigophora and Rhizopoda and the second with the Sporozoa and Ciliophora. It is perhaps a mark of the advance of our knowledge of the Protozoa that 1,213 pages, each of them closely packed with detail, are required to record the essence of what we know about this remarkable group of organisms. The reader will marvel that one man can encompass so wide a range of detail; but Prof. E. Reichenow proves that he, at any rate, can, and every protozoologist will be grateful for the immense labour and care that he has put into this work. For there is no other book in any language that gives us all that "Doflein" does. Wenyon's great work, "Protozoology", with its wide range and emphasis on the pathogenic species, is unhappily out of print, and only the fortunate possessors of copies of it can enjoy and profit by its fine illustrations and its invaluable bibliography. It is a great pity that a revised edition of it has not been published.

But "Doflein" remains. Although it deals less fully than Wenyon did with the pathogenic species. this new edition will surely find a place in every biological library, and zoologists who work on the beautiful and thought-provoking non-pathogenic species will scarcely be able to do without it. They will welcome the return, in this second part of the book, of paper which gives back to the illustrations the quality they had in the earlier editions. Perhaps it will be possible to re-issue the first part on the same kind of paper. Though it increases the weight of the book, that is a justifiable price to pay for the added quality of the illustrations.

There is no space, in a brief review, to discuss in detail the contents of the book; nor is it likely that some readers will not find controversial statements somewhere or other in the three volumes, which cover so wide a field. A critic might, for example, select for discussion Prof. Reichenow's removal of the Theileridae and Babesidae from the Haemosporidia and his view that species of these families were not originally parasites of ticks. This view depends largely on work done by Prof. Reichenow himself and his colleagues. Logical though the views expressed will seem if this work and Prof. Reichenow's somewhat summary dismissal of earlier work are accepted, some readers will require further evidence before they will abandon the older views completely.

Whatever their criticisms, however, readers will be as grateful to Prof. Reichenow as they have been to Doflein, who created this great book. Other books on the Protozoa have appeared recently, and each of these has its own quality and value; but none has yet excelled "Doflein". English-speaking readers would no doubt be even more grateful if the book could be translated into English. This would not be a difficult task, because a feature of "Doflein" has always been the clear and relatively simple German in which it is written.

G. LAPAGE

\section{TEXTILE FIBRES}

\section{The Identification of Textile Fibres}

Qualitative and Quantitative Analysis of Fibre Blends. By Bruno Luniak. (Translated and Revised by the Author from the Second Edition of Communication No. 3 of the Department of Textile Engineering and Textile Industries at the Swiss Federal Institute of Technology in Zurich.) Pp. xiv $+177+52$ plates. (London: Sir Isaac Pitman and Sons, Ltd., 1953.) $45 s$. net.

MR. BRUNO LUNIAK wrote the first Swiss 11 edition of his text-book whilst working with Prof. Honegger at the Technische Hochschule in Zurich. This was published in 1945. A second Swiss edition followed in 1949. The author is now working at the Linen Industry Research Association near Belfast, and encouraged by the success of his German version and by his British environment has translated his book into English; whilst doing this he has revised and enlarged the text, has increased the collection of photomicrographs and has added an index. All these changes have made the new 